\title{
New data on an exotic Nippotaenia mogurndae (Cestoda), newly introduced to Europe
}

\author{
L. KOŠUTHOVÁ, J. KOŠČO ${ }^{1}$, D. MIKLISOVÁ², V. LETKOVÁ, P. KOŠUTH, P. MANKO ${ }^{1}$ \\ Department of Parasitology, Diseases of Fish, Bees and Game, University of Veterinary Medicine, Komenského 73, \\ 04181 Košice, Slovakia; E-mail: kosuthova@uvm.sk; ${ }^{1}$ Faculty of Human and Natural Sciences, University of \\ Prešov, 17. novembra 1, 08116 Prešov, Slovakia; ${ }^{2}$ Institute of Zoology SAS, Košice, Slovakia
}

\begin{abstract}
Summary
Data on prevalence and current distribution of the cestode Nippotaenia mogurndae Yamaguti and Miyata, 1940 (Nippotaeniidea) in Slovakia, are provided. A total of 163 fish from 8 localities of different types in the Tisa River basin were infected with $N$. mogurndae. The mean intensity of infection was 1.8 with a maximum of 5 tapeworms. The expansion of the distribution of the cestode corresponds well with the spreading of its host, the invasive fish Amur sleeper Perccottus glenii Dybowski, 1877. The Spearmann correlation coefficient was used to test the relationship between the intensity of infection and standard length of the fish $(\mathrm{r}=0.36 ; \mathrm{n}=163 ; \mathrm{P}<0.05)$, condition coefficient of the fish $(\mathrm{r}=0.22 ; \mathrm{n}=115 ; \mathrm{P}<0.05)$ and season $(\mathrm{r}=-0.37 ; \mathrm{n}=$ $355 ; \mathrm{P}<0.05$ ). A significant correlation was confirmed for each pair of variables. There is a statistically significant difference between the prevalence of the cestode in two functional size groups $(\mathrm{t}=3.28 ; \mathrm{n}=163 ; \mathrm{P}<0.05)$. The prevalence of the cestode increased with the standard length of fish. The potential risk of further expansion of $N$. mogurndae to other countries is discussed.
\end{abstract}

Key words: Nippotaenia mogurndae, non-native species, Amur sleeper, risk of invasion, Tisa River basin

\section{Introduction}

Spontaneous migration or dispersal of exotic fish species (connected with human activities) beyond their natural ranges and the localities of their initial introduction represents recently a serious problem and threat. Expansion of the Amur sleeper, Perccottus glenii Dybowski, 1877 (Perciformes: Odontobutidae), a freshwater invasive fish with its origin in East Asia (Reshetnikov, 2004) to Eastern Europe, had as one of its consequences also the introduction of the exotic cestode Nippotaenia mogurndae Yamaguti and Miyata, 1940 to Slovakia (Košuthová et al., 2004; Bombarová et al., 2005). This is a member of a small order
Nippotaeniidea known only from the freshwater fishes of Japan, China, New Zealand and Russia (Akhmerov, 1941; Dubinina, 1962, 1971, 1987; Hine, 1977; Bray, 1994). The cestode has a complex life cycle that involves one intermediate host - a planktonic copepod (Copepoda: Cyclopoida) such as the Diaptomus incongruens, Eucyclops serrulatus, Mesocyclops leuckarti and Mesocyclops crassus (Demshin, 1985; Pronin et al., 1998).

In this paper, data on the current distribution and prevalence of Nippotaenia mogurndae in eastern Slovakia are presented.

\section{Material and Methods}

Study area

The study was conducted in the localities of East Slovakian Lowland, in the original floodplain of the Latorica, Bodrog and Tisa Rivers $\left(21^{\circ} \mathrm{N}, 48^{\circ} \mathrm{E}\right)$ (Fig. 1). Fish were sampled from 12 sampling sites (drainage canals, oxbows and borrow pits), all belonging to the upper part of the Tisa River (Fig. 2). The area comprises a network of interconnected drainage canals, which cover the whole territory. During floods, water in the canals flows in the opposite direction and all canal networks and normally isolated habitats are connected. As demonstrated by earlier observations (Koščo et al., 2003), populations of $P$. glenii were mostly abundant in microhabitats with aquatic vegetation.

\section{Field and laboratory methods}

From May 2003 to April 2006 a total of 432 P. glenii from 12 localities were examined for helminth parasites. The fish were caught predominantly by electrofishing (using a direct pulsating electric current $170-220 \mathrm{~V}, 0.5-3.5 \mathrm{~A}$ ). The number and frequency of samples corresponded with the fluctuated level of Amur sleeper density in the sampling sites (Koščo et al., 2003). All fish were placed into aerated tanks and carried alive to the laboratory. Each 
specimen was individually killed and examined by necropsy (Ergens \& Lom, 1970). Standard length (S1) of fish ranged between $18.0-103.8 \mathrm{~mm}$. Cestodes isolated from the host's intestine were washed in saline, fixed in hot $4 \%$ formaldehyde and determined using morphological characters by Dubinina $(1971,1987)$. In fact, that Nippotaenia is hyperapolytic, only the complete bodies with scolex were counted.

\section{Data analysis}

Parasite infection was characterized by the prevalence and mean and maximum intensity of infection (Bush et al., 1997).

The cluster analyses yielded functional groups of distinct diet composition that were highly size-dependent. Based on the frequency of food components, two functional groups ( $\mathrm{Sl}$ ) were defined in Amur sleeper populations: 1) size $<70 \mathrm{~mm}$ and 2) size $\geq 70 \mathrm{~mm}$. Copepods dominated in lower size classes, cannibalism was significant from 80 mm (Koščo et al., 2008). Difference between the prevalence of cestode in these groups was tested by t-test for percentage values after arcsin transformation. Spearmann correlation coefficient was used to test the relationship between the Sl groups intensity of infection of N. mogurndae, the intensity of infection and condition coefficient of the fish host $(\mathrm{K})\left(\mathrm{K}=\mathrm{m} / \mathrm{l}^{3}\right)$ and between the intensity of infection and season $(\mathrm{m}=$ weight, $1=$ length $)$. Statgraphics 4.0 (Koschin, 1992) software was used to calculate this coefficient.

\section{Results}

Occurrence of Nippotaenia mogurndae

In eastern Slovakia, in the so called Medzibodrozhie region the Amur sleeper has recently rapidly spread with increasing density (Fig. 1) and the expansion of its cestode corresponds well with the host distribution (Fig. 2). Localities where $N$. mogurndae is present are situated most frequently in flooded areas. The dissemination of the parasite is significantly influenced by high water levels and the connected floods as reported by Elovenko (1981) that also was the case of the Bodrog and Tisa drainage areas in eastern Slovakia (Koščo et al., 2003).

A total of 163 fish from 8 localities were infected with $N$. mogurndae. The mean intensity of infection was 1.8 with a maximum of 5 tapeworms. The increasing tendency of the average and maximum prevalence within the years in sampling sites Svätá Mária and Somotor has been registered (Fig. 3a, b). The values of prevalence in Svätá Mária sampled repeatedly in April and May 2003 - 2006 ranged between $40.6-81.0 \%$ (Table 1 ) and the mean intensity of infection was 2.1 .

\section{Relationship of Nippotaenia mogurndae infection versus fish size and season}

The prevalence of cestodes in the functional size group S1 $<70 \mathrm{~mm}$ was $57 \%(125 / 71)$ and in the functional group Sl $\geq 70 \mathrm{~mm}$ the prevalence reached $84 \%(38 / 32)$. There is a

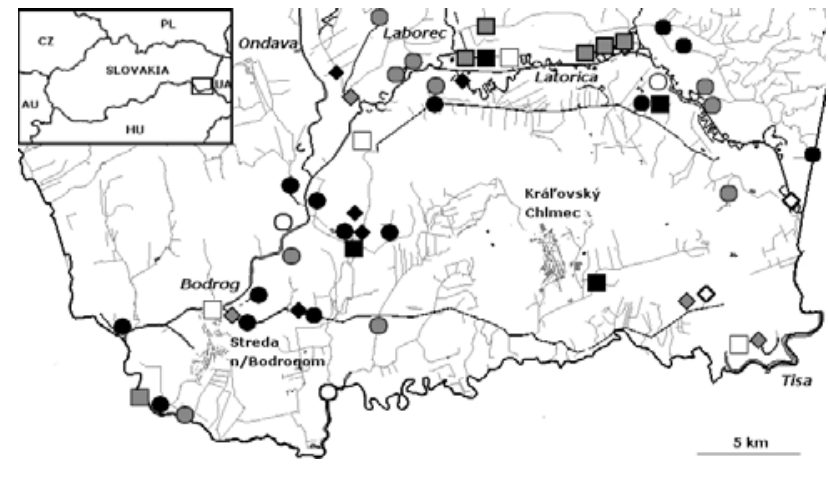

Fig. 1. Spreading of Perccottus glenii in Slovakia during the study period (2003 - diamond, 2004 - circle, 2005 - square) and its relative abundance (white $<5 \%$, grey $5-30 \%$, black $>30 \%$ ) in positive localities.

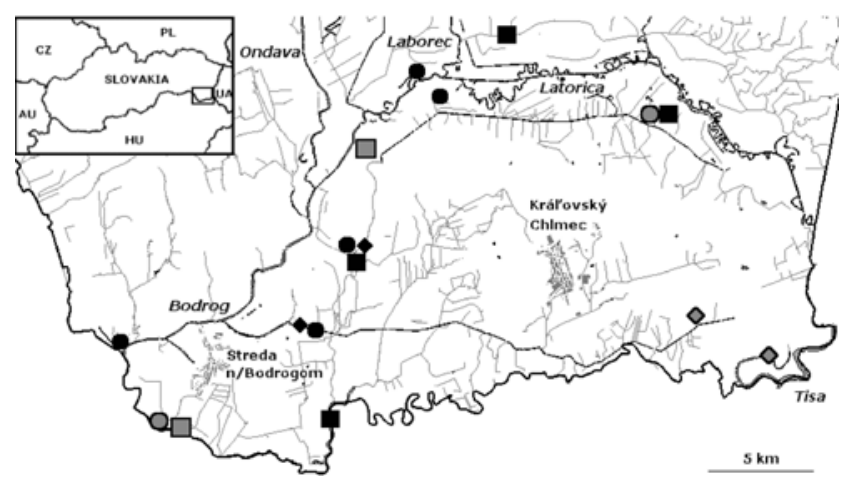

Fig. 2. Distribution of N. mogurndae in Slovakia - positive (black) and negative (grey) localities during the study period (2003 - diamond, 2004 - circle. 2005 - sauare)

statistically significant difference between the prevalence of the cestode for two functional size groups $(\mathrm{t}=3.28 ; \mathrm{n}=$ 163 ; $\mathrm{P}<0.05)$. Intensity of infection was observed to increase with the increasing $\mathrm{Sl}$ of the fish $(\mathrm{r}=0.37 ; \mathrm{n}=163$; $\mathrm{P}<0.05)$. The significant association was confirmed also for the relation of condition coefficient of the fish and intensity of infection $(\mathrm{r}=0.22 ; \mathrm{n}=115 ; \mathrm{P}<0.05)$.
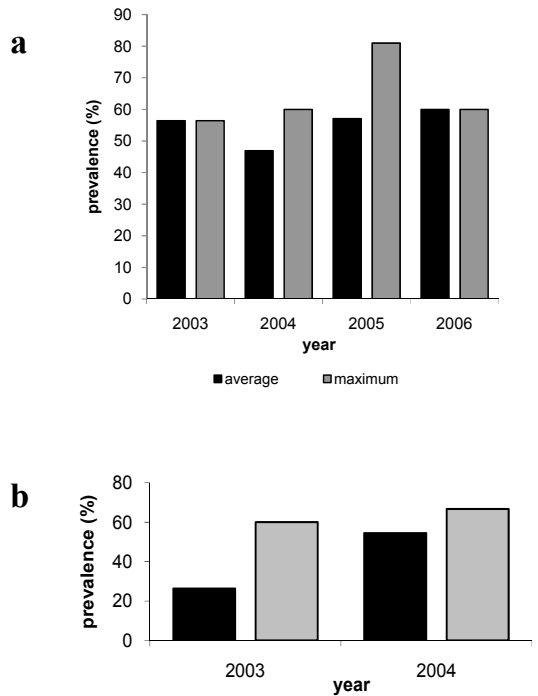

Fig. 3. Increasing tendency of $N$. mogurndae prevalence in Bodrog River basin, sampling sites Svätá Mária (a) and Somotor (b). 
Table 1. The prevalence of Nippotaenia mogurndae in Perccottus glenii

\begin{tabular}{|c|c|c|c|c|c|}
\hline \multicolumn{3}{|c|}{ Localities investigated } & \multirow{2}{*}{ Date } & \multirow{2}{*}{ No. of fish } & \multirow{2}{*}{$\begin{array}{l}\text { Prevalence } \\
\quad(\%)\end{array}$} \\
\hline Sampling site & River drainage & Biotop & & & \\
\hline \multirow[t]{8}{*}{ Svätá Mária } & \multirow[t]{8}{*}{ Bodrog } & \multirow[t]{8}{*}{ canal } & May, 2003 & 117 & 56.4 \\
\hline & & & May, 2004 & 32 & 40.6 \\
\hline & & & July, 2004 & 25 & 52.0 \\
\hline & & & September, 2004 & 2 & $1 / 2$ \\
\hline & & & November, 2004 & 5 & 60.0 \\
\hline & & & April, 2005 & 21 & 81.0 \\
\hline & & & October, 2005 & 14 & 21.4 \\
\hline & & & April, 2006 & 10 & 60.0 \\
\hline \multirow[t]{6}{*}{ Somotor } & \multirow[t]{6}{*}{ Bodrog } & \multirow[t]{6}{*}{ canal } & April, 2003 & 5 & 60.0 \\
\hline & & & May, 2003 & 31 & 22.6 \\
\hline & & & July, 2003 & 2 & 0.0 \\
\hline & & & April, 2004 & 3 & $2 / 3$ \\
\hline & & & May, 2004 & 3 & $2 / 3$ \\
\hline & & & September, 2004 & 5 & 40.0 \\
\hline \multirow{3}{*}{$\begin{array}{l}\text { Zatín } \\
\text { Borša } \\
\text { Oborín }\end{array}$} & \multirow{3}{*}{$\begin{array}{l}\text { Latorica } \\
\text { Bodrog } \\
\text { Laborec }\end{array}$} & \multirow{3}{*}{$\begin{array}{l}\text { borrow pit } \\
\text { borrow pit } \\
\text { oxbow }\end{array}$} & June, 2004 & 3 & $1 / 3$ \\
\hline & & & July, 2004 & 11 & 54.5 \\
\hline & & & August, 2004 & 11 & 27.3 \\
\hline \multirow[t]{2}{*}{ Leles } & \multirow[t]{2}{*}{ Latorica } & \multirow[t]{2}{*}{ oxbow } & November, 2004 & 11 & 0.0 \\
\hline & & & September, 2005 & 33 & 9.0 \\
\hline Vel'ký Kamenec & Bodrog & oxbow & April, 2005 & 7 & 71.4 \\
\hline Beša & Latorica & canal & July, 2005 & 12 & 58.3 \\
\hline \multicolumn{4}{|c|}{ Total fish examined from positive localities } & 363 & \\
\hline
\end{tabular}

Seasonal differences in occurrence of $N$. mogurndae were observed. Fish were more heavily infected in spring (samples in April and May, with values of prevalence usually between $60-80 \%$ ) than in summer (June - August, $30-$ $55 \%$ ) and autumn (September and November, $40-60 \%$ ). The decreasing tendency of the prevalence between individual seasons in the most sampled site - Svätá Mária, has been observed (Fig. 4). Significant variation was found in intensity of infection in different months $(\mathrm{r}=-0.37 ; \mathrm{n}=$ 355; $\mathrm{P}<0.05)$.

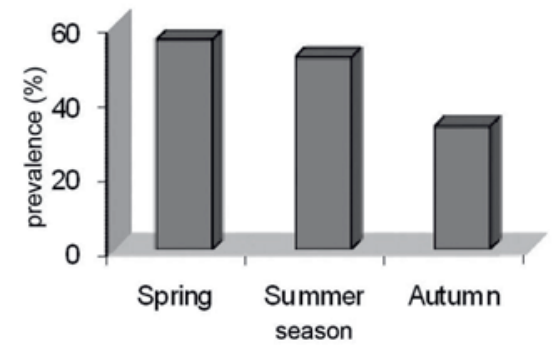

Fig. 4. Decreasing tendency of prevalence within the seasons in the locality Svätá Mária.

\section{Discussion}

Pronin et al. (1998) recorded Nippotaenia mogurndae as the dominant parasite of the Amur sleeper in the Baikal
Region (prevalence up to $71.8 \%$ ). Ermolenko (2004) has also confirmed this cestode species in $P$. glenii from water basins of the Primorsk Region (the Amur River basin). The present study demonstrates that $N$. mogurndae has become a common parasite of the Amur sleeper in East Slovakia since its first finding in 2003 (Košuthová et al., 2004). However, the risk of further expansion of this invader is fairly high because drainage canals, where the parasite occurs, are interconnected during the floods. This fact increases the risk of the cestode transfer with Amur sleeper populations to new localities and even outside Slovakia through the Tisa River that connects the region with the Danube River.

Spreading of the cestode in the last decades is apparently due to the rapid expansion of its definitive host, which has become the dominant or even exclusive species in the local fish communities in this region of Slovakia (Koščo \& Košuth, 2002; Koščo et al., 2003). The life cycle of this cestode, which includes copepod species common also in Europe (Terek, 1990), also contributes to the ability of $N$. mogurndae to establish in the regions very distant from its original distributional area, similarly as it was the case of another successful tapeworm colonizers, the pseudophyllidean Bothriocephalus acheilognathi Yamaguti, 1934 (see, e.g., Kennedy, 1993; Scholz, 1999; Salgado-Maldonado \& Pineda-López, 2003), Khawia si- 
nensis Hsü, 1935 (Chubb \& Yeomans, 1958) or Atractolytocestus huronensis Anthony, 1958 (Chubb et al., 1996; Oros et al., 2004).

The tendency of $N$. mogurndae to prevail in larger fish, indicated by the present data, may be related to the postcyclic transmission, i.e. transfer of cestodes via cannibalism. According to Koščo et al. (2008) the frequency of cannibalism increased in fish larger than $60 \mathrm{~mm}$. On the contrary, Ermolenko (2004) observed heavier infections in smaller fish, which, however, might be related to the different ecological conditions in the Primorsk Region. Positive correlation between the infection rate and size of fish hosts was previously observed in many fish helminth parasites, including tapeworms (for review see Chubb, 1982). Similarly, the postcyclic transmission has been proven for numerous helminths (Odening, 1976; Moravec, 1979, 1984; Priemer, 1987; Kennedy, 1999; Nickol, 2003 etc.).

Variation in the intensity of infection with N. mogurndae in different months is probably related to the seasonal occurrence of copepods (Terek, 1990). Crustaceans form a dominant part of fish diet in April; thereafter the frequency of crustaceans in diet of fish decreases (Koščo et al., 2008).

The present results show the necessity to study the parasite fauna, adaptation and life cycles of $P$. glenii and other invasive fishes. Increasing findings of $N$. mogurndae entail the risk of its potential transfer to native or endemic species with the same ecological niche like Umbra krameri (Walbaum, 1792). Laboratory experiments are necessary to clarify the possible role of cannibalism in the accumulation of $N$. mogurndae tapeworms in larger Amur sleeper.

\section{Acknowledgements}

Thanks are due to anonymous reviewers for constructive criticism on manuscript and Mgr. L. Pekárik for technical support. The study was supported by the Slovak Grant Agency VEGA, projects No. 1/0352/08, 1/2406/05 and APVV project No. 0154-07.

\section{References}

AKHMEROV, A. K. (1941): Amurotaenia perccotti n. g. Vertreter einer neuen Cestoden-Ordnung. Dokl. AN SSSR, 30: $191-192$

BRAY, R. A. (1994): Order Nippotaeniidea Yamaguti, 1939. In KhaliL, L. F., Jones, A., BRAY, R. A (Eds): Keys to the Cestode Parasites of Vertebrates. CAB International, Wallingford

Bush, A. O., Lafferty, K. D., Lotz, J. M., Shostak, A. W. (1997): Parasitology meets ecology in its own terms: Margolis et al. revised. J. Parasitol. Vol. 20: 575 - 583

ChubB, J. C. (1982): Seasonal occurrence of helminths in freshwater fishes. Part IV. Adult Cestoda, Nematoda and Acanthocephala. Adv. Parasitol., 20: 1 - 292

ChubB, J. C., KirK, R., Wellby, I. (1996): Caryophyllaeid tapeworm Atractolytocestus huronensis Anthony, 1958 (=
Markevitschia sagittata Kulakovskaya et Akhmerov, 1965) in carp Cyprinus carpio L. in British Isles - another translocation? Abstr. of the Spring meeting of the British Society of Parasitol. 1 - 3 April, Bangor: University of Wales, Bangor, p.66

ChubB, J. C., Yeomans, W. E. (1995): Khawia sinensis Hsü, 1935 (Cestoda: Caryophyllidea), a tapeworm new for the British Isles: a threat to carp fisheries? Fish. Man. Ecol. Vol. 2: $263-277$

DEMSHIN, N. I. (1985): Postembryonal development of cestode Nippotaenia mogurndae (Nippotaeniidea, Nippotaeniidae). Parazitologiya, 19: $39-43$

DubininA, M. N. (1962): Class tapeworms Cestoidea Rud., 1801. In BYKhOvskiI B. E. (Ed): Key to the Parasites of Freshwater Fish of the SSSR. Izd. Akad. Nauk USSR, Moscow-Leningrad

DubininA, M. N. (1971): Cestodes from fishes of River Amur basin. Parasitol. Sb., 255: 77 - 119

DubininA, M. N. (1987): Class flatworms - Cestoda Rudolphi, 1808. In BAUER O. N. (Ed): Key to the Parasites of Freshwater Fish of the SSSR. Second Edition Vol. 3, Part 2. Nauka, Leningrad

ElovenKo, V. N. (1981): Systematic status and geographical distribution of fish from family Eleotridae (Gobioidei, Perciformes) introduced into the waterbodies of European part of the USSR, Kazakhstan and Central Asia. Zool. Zh., 60: $1517-1522$

ERGEns, R., LOM, J. (1970): Causative agents of fish diseases. Academia, Prague

ERMOLEnKO, A. V. (2004): Parasite fauna of Amur sleeper Perccottus glehni (Eleotridae). Parazitologiya, 3: 251 256

Hine, P. M. (1977): New species of Nippotaenia and Amurotaenia (Cestoda: Nippotaeniidea) from New Zealand fresh water fishes. J. R. Soc. N. Z. Zool., 4: $143-155$

Kennedy, C. R. (1999): Post-cyclic transmission of Pomphorhynchus laevis (Acanthocephala). Folia Parasitol., 46: $111-116$

KoschIN, F. (1992): Statgraphics or the statistics for everyone. Grada, Praha KENNEDY, C. R. (1993): Introductions, spread and colonization of new localities by fish helminth and crustacean parasites in the British Isles: a perspectives and appraisal. J. Fish Biol., 43: 287 - 301

KOŠČO, J., KOŠUTH, P. (2002): On the occurrence of Perccottus glenii Dybowski, 1877 and Ictalurus melas Rafinesque, 1820 from the East Slovakia. In LUSK, S., LUSKOVÁ, V., HALAČKA, K. (Eds): Biodiversity of fishes in the Czech Republic (IV.). Institute of Vertebrate Biology, Brno

KošČO, J., LuSK, S., HALAČKA, K., LuSKOVÁ, V. (2003): The expansion and occurrence of the Amur sleeper (Perccottus glenii) in eastern Slovakia. Folia Zool., 52: 329 336

KoŠČO, J., Manko, P., MiKlisovÁ, D., KošuthovÁ, L. (2008): Feeding ecology of invasive Perccottus glenii in Slovakia. Czech J. Anim. Sci., 52: (in press)

Košuthová, L., Letková, V., KošČO, J., Košuth, P. (2004): First record of Nippotaenia mogurndae Yamaguti 
and Miyata, 1940 (Cestoda: Nippotaeniidea), a parasite of Perccottus glenii Dybowski, 1877, from Europe. Helminthologia, 41: 55 - 57

MORAVEC, F. (1979): Occurrence of the endoparasitic helminths in pikes (Esox lucius L.) from the Mácha Lake fishpond system. Věst. Čsl. Spol. Zool., 43: $174-193$

MORAVEC, F. (1984): General aspects of the bionomy of parasitic nematodes (Nematoda) of freshwater fishes. Academia, Praha

NiCKOL, B. (2003): Is postcyclic transmission underestimated as an epizootological factor for acanthocephalans? Helminthologia, 2: 93 - 95

ODENING, K. (1976): Conception and terminology of hosts in parasitology. Adv. Parasitol., 14: 1-93

Oros, M., Hanzelová, V., Scholz, T. (2004): The cestode Atractolytocestus huronensis (Caryophyllidea) continues to spread in Europe: new data on the helminth parasite of the common carp. Dis. Aquat. Org., 62: $115-$ 119

PrIEMER, J. (1987): On the life-cycle of Proteocephalus exiguus (Cestoda) from Salmo gairdneri (Pisces). Helminthologia, 24: $75-85$

Pronin, N. M., Selgebi, D. Kh., Litvinov, A. G., ProninA, S. V. (1998): Comparative ecology and parasitofauna of exotic immigrants in great lakes of the world: Perccottus glehni from lake Baikal and Gymnocephalus cernuus from lake Verkhnee. Sib. Ekol. Zhur., 5: 397 - 406 Reshetnikov, A. N. (2004): The fish Perccottus glenii: history of introduction to western regions of Eurasia. $\mathrm{Hy}$ drobiologia, 522: 349 - 350

SAlgado-Maldonado, G., PinedA-LóPez, R. F. (2003): The Asian fish tapeworm Bothriocephalus acheilognathi: a potential threat to native freshwater fish species in Mexico. Biol. Invasions, 5: $261-268$

Scholz, T. (1999): Parasites in cultured and feral fish. Vet. Parasitol., 84: 317 - 335

TEREK, J. (1990): Net zooplankton of hydromeliorational canals and its relation to selected ecological factors. Biologia, Bratislava, 45: $801-814$

ACCEPTED MARCH 15, 2008 